\title{
Hva er portrettets diagnose?
}

\author{
Det eksisterte i flere hundre år en \\ tro på at leger kunne diagnostisere \\ sykdommer ut fra portretter.
}

I løpet av 1400- og 1500-tallet ble ikkereligiøse motiver likestilt med kristen kunst. Vi har et stort kildemateriale fra denne perioden, hovedsakelig fra NordItalia, som diskuterer kunstens egenskaper. Det malte eller hugne bilde hadde gjennom middelalderen fungert som et medium for fortellinger om opphøyede sannheter. I den religiøse kunsten ble Guds plan for jorden, slik Bibelen og helgenfortellingene skildret den, åpenbart for menneskene. Disse forestillingene ser ut til å ha blitt overført også til den ikke-religiøse kunsten. Spor av dette kan kildebelegges til et godt stykke ut på 1700-tallet.

Den italienske maleren, arkitekten og skulptøren Leon Battista Alberti (1404-72) påsto for eksempel at portretter har evnen til å gjøre fraværende menn tilstedeværende og vekke de døde til live. Dette kan man tolke på flere måter. For å forstå hva han mener må man først akseptere hvor spesielt et malt portrett må ha virket for mennesker som levde i en tid da maleri og skulptur var de eneste medier som avbildet verden og speilet knapt var utviklet. I tillegg var portretter frem til midten av 1600 -tallet svært sjeldne og kun forbeholdt de aller rikeste. Giotto (1267-1337) kalles den første renessansemaler og var trolig en av de første kunstnere siden antikken som fremstilte mennesker med gjenkjennbare følelsesutrykk. Da hans bibelske scener første gang ble vist, brøt det ifølge sam- tidige kilder ut full forvirring i kirkene fordi folk trodde maleriene var levende. Når man ser dem i dag, virker dette søkt, men dersom ingen noensinne før hadde sett mennesker malt på denne måten, må effekten allikevel ha vært voldsom. Troen på at bildene var bærere av magi, sammen med portrettenes ytterste sjeldenhet, kan være med på å forklare Albertis utsagn. Han beskrev trolig det de fleste faktisk trodde og opplevde i møtet med et portrett.

Et annet eksempel på troen på portretters iboende egenskaper er bruken av kunst som grunnlag for ekteskapsinngåelser på 1400- og 1500-tallet. Dette var en alvorlig sak, fordi bildet ofte dannet grunnlaget for vurderinger av den portrettertes personlighet og helsetilstand. En god maler skulle kunne overføre hele den portrettertes person til lerretet og ble ofte holdt ansvarlig dersom modellen ikke levde opp til forventningene. Leger ble ofte også kalt inn for å vurdere alt fra temperament til fertilitet og robusthet - og ikke minst balansen mellom de fire kroppsvæskene - basert på maleriet. Et kjent eksempel på dette er kong Henrik VIIIs ekteskap med Anna av Kleve i 1539/40. Det mulige ekteskapet mellom den engelske kongen og en datter av hertugen av Kleve dannet grunnlaget for en viktig allianse, og maleren Hans Holbein (1497-1583) ble sendt til byen Düren for å male de to prinsessene av Kleve. Da han vendte tilbake til det engelske hoff medbringende portrettene, ble kongen svært fornøyd og pekte etter kort tid ut prinsesse Anne som sin foretrukne brud. Kongen tilkalte så sine livleger, som grundig undersøkte portrettet for tegn på sykdom, infertilitet eller sinnslidelser. De friskmeldte henne med en liten kommentar om et mulig kolerisk temperament. Kongen sendte da sin førsteminister til Düren for å forhandle ekteskapskontrakten ferdig og ventet i spenning på sin brud.

Henrik VIIIs møte med Anna av Kleve i Rochester året etter har skrevet seg inn i historiebøkene. En av fortellingene sier at han umiddelbart etter å ha festet blikket på henne for første gang så bort og ba om et stort glass brandy. Kongen var overhodet ikke fornøyd med forholdet mellom Holbeins portrett og modellen. På grunn av ekteskapskontraktens vanntetthet og faren for å fornærme en viktig alliansepartner måtte kongen motvillig gifte seg med prinsessen, men ekteskapet ble annullert allerede 26. juli samme år, med begrunnelsen at det ikke var fullbyrdet. Kongens førsteminister ble senere samme år dømt for forræderi og henrettet, Hans Holbein mistet sin rolle som kongens foretrukne maler, og samtlige livleger som hadde diagnostisert bildet, mistet sine stillinger ved hoffet med begrunnelsen at de hadde oversett dronningens frigide tilbøyeligheter.

Det å vurdere en pasients helse basert på hans eller hennes portrett ser ut til å ha forsvunnet som praksis i løpet av 1600 tallet. I samme periode forsvinner også diagnostisering med utgangspunkt i balansen mellom de fire kroppsvæskene. Ekteskap basert på portretter var til tross for denne utviklingen vanlig praksis i Vest-Europa helt til siste halvdel av 1700-tallet.

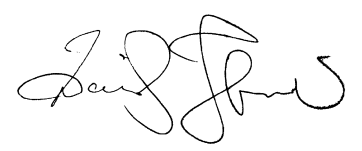

